\title{
Cynicism as Immanent Critique: Diogenes and the Philosophy of Transvaluation
}

\author{
Darren Gardner | ORCID: 0000-0001-7852-2560 \\ Department of Philosophy, Vrije Universiteit, Amsterdam, the Netherlands \\ darrengardner@mac.com
}

\begin{abstract}
I argue that Diogenes and early Cynicism can be understood in an explicitly social and political context, where Cynic praxis, performative public action, can be seen to make visible oppositions inherent to the polity. In doing so, Diogenes' praxis should be understood as a form of immanent critique, one that demonstrates, for example, that nature and custom (phusis and nomos) are interrelated oppositions in the polis. Cynicism here is understood as a form of immanent critique because Diogenes challenges the social norms of the polis without endorsing external universal standards or predetermined models, but from illuminating dynamics from within the polis and polity.
\end{abstract}

\section{Keywords}

Cynicism - Diogenes - critique - ancient philosophy - ancient political theory - social normativity

\section{Introduction}

Diogenes of Sinope was by all accounts, strange - atopos. A double folded cloak, walking stick and wallet, his striking appearance and way of life was an oddity. But as a nonconformist, his heroic frank speech and contrarian actions made him a highly influential figure; a true philosophical cause célèbre. He has been a subject of inquiry from Cicero to Foucault, exiled to the margins of intellectual and academic discourse from time to time, but returning when the climate is right for counterculture and philosophical provocation. There has 
been another uptick in scholarship on Diogenes, expanding our understanding of various aspects of early Cynicism, especially the forms of comedic and rhetorical communication that he and other cynics employed. But he is more than a comic figure, more than a jester or bōmolokhos. As a social and political dissident, a proto-anarchist in the sense of challenging political authority, Diogenes provoked seemingly radical views and challenged conformity to customs and social norms (Diog. Laert. 6.71). It is no wonder that thinkers like Diderot, Nietzsche, and Foucault were powerfully inspired by his legacy and tried to reignite Diogenes' famous lantern in their own way, in their own time. ${ }^{1}$

The ancient anecdote tradition about Diogenes known as khreiai can appear at first blush to be rather philosophically thin. ${ }^{2}$ Diogenes can easily be mistaken for a moral theorist who promoted the virtues of a life in accord with nature (phusis) rather than social convention (nomos). The natural superiority of the sun over the political power of Alexander, the example of the mouse that revealed to Diogenes how very little is needed to thrive, and the public performances of natural bodily functions attest to a view that life according to nature, kata phusin, ought to be promoted as true north. ${ }^{3}$ In this way Diogenes is sometimes seen as a mere naturalist, that is, living in accordance with brute nature or a natural animalistic ethos, but this is controversial because the use of kata phusin can and I believe should be understood here to mean something

1 L. Shea, The Cynic Enlightenment:Diogenes in the Salon (Baltimore: Johns Hopkins University Press, 2010), p. $45 \mathrm{ff}$.

2 The Cynic legacy is tied to the anecdote tradition that is witty, playful, self-aware, and full of complex meaning. While the anecdotes are not likely directly authored by Diogenes himself, there are good reasons to think that he was nevertheless responsible for fashioning much of the information in the accounts, if not spreading them in some form. Much of the anecdotal material about Diogenes will be referenced from Diogenes Laertius' Lives of Eminent Philosophers, book 6, and the references to Diogenes and the Cynics from Epictetus, Julian, and Hellenistic sources. Other anecdotal material, for example, collected from G. Giannantoni (ed.), Socratis Socraticorum Reliquiae (Nápoles: Bibliopolis, 199o) and A. Malherbe (ed.), The Cynic Epistles (Atlanta: the Society of Bibilical Literature, 20o6) offer additional important material on Cynicism and Diogenes. See also M. Usher, 'Diogenes' Doggerel: Chreia and Quotation in Cynic Performance', Classical Journal 104 (2009), pp. 207-223; and I. Sluiter, 'Communicating Cynicism: Diogenes' Gangsta Rap', in M. Frede and B. Inwood (eds.), The Philosophy of Language in the Hellenistic Age (Cambridge: Cambridge University Press, 2005), pp. 139-163.

3 Diog. Laert. 6.22; Diog. Laert. 6.71; Julian. Or. 6.193d. See Dio Chrys. Or. 6 in Dio Chrysostom: Discourses 1-11,J. Cohoon (trans.) (London:Harvard University Press, 1939) and Pseudo-Lucian, The Cynic. Diogenes can also be understood to be embodying kat' eleutherian, a life according to freedom, and in this sense resisting problematic laws and customs, but without requiring the animalistic reading of kata phusin. If Diogenes expresses a philosophy of naturalness by virtue of his doggishness as such, we might emphasize the fact that human reason, which is both employed and endorsed by Diogenes, is not symmetrical with canine reason. 
like 'in accordance with our nature,' which includes, for example, reason. While a mouse exhorts Diogenes to rethink his behavior, the point is not to live mouselike, but to reconsider our choices, which is a task for reflective human minds, not dogs, mice, or animality in general. Seeing Diogenes as doggish likewise is not a model for behavior as such, but a provocation to rethink our normative behaviors.

Since Diogenes also challenged the authority of power and the civic social norms, some scholars emphasize how the early Cynics exemplified a new spirit of individualism and even anti-statism, ${ }^{4}$ while others emphasize the importance of Cynic frank speech (parrhēsia). ${ }^{5}$ 'Asked what is the most beautiful thing in men, he [Diogenes] said "frank speech (parrhēsia)"' (Diog. Laert. 6.69). Some connect Cynic parrhesia to comedic performance theories, while others have emphasized Cynic eudaemonism. All of this contributes to our understanding of the 'Socrates gone mad', as Plato supposedly called him, and yet Diogenes can still appear problematically ambiguous. One might be hard pressed to define any strict philosophical doctrine and yet it is also insufficient to merely see him as a comic literary figure. This is particularly true because, at a minimum, he was the philosophical mentor for Crates and Hipparchia, and because Zeno and the early Stoic thinkers were highly influenced by Diogenes. ${ }^{6}$

While scholarship has emphasized individualism, anti-statism, eudaemonism, or naturalism, including also the importance of parrhēsia and Diogenes' connection to comedic performance theory, scholarship has yet to fully consider central social and political aspects of Diogenes' Cynicism. ${ }^{7}$ To this

4 On individualism: D. Dudley, The History of Cynicism (London: Methuen and Co., 1937), p. 37; On anti-statism: F. Sayre, 'Greek Cynicism', The Journal of the History of Ideas 6 (1945), pp. $113-118$.

5 M. Foucault, The Courage of Truth (the Government of Self and Others 2): Lectures at the Collège De France 1983-1984 (New York: Palgrave Macmillan, 2011); K. Kennedy, 'Cynic Rhetoric: The Ethics and Tactics of Resistance' Rhetoric Review 18 (1999), pp. 26-45; S. Halliwell, 'Comic Satire and Freedom of Speech Classical Athens', Journal of Hellenic Studies 111 (1991), pp. 48-70; J. Kindstrand, Bion of Borysthenes: A Collection of the Fragments with Introduction and Commentary (Stockholm: Almqvist and Wiksell, 1976), p. 45; See also Plut. Brut. 34.5; Luc. Demon. 5 o.10.

6 Zeno's Republic is said to have been written 'on the dog's tail' referring to Diogenes himself (Diog. Laert. 7.4).

7 On Diogenes and Cynicism: C. Turner, 'Cynic Philosophical Humor as Exposure of Incongruity', Epoche 24 (2019), pp. 27-52; W. Desmond, The Greek Poverty: Origins of Ancient Cynicism (Notre Dame: Notre Dame University Press, 20o6); L. Navia, Classical Cynicism (Connecticut and London: Greenwood Press, 1996); R. Branham, and M. Goulet-Cazé, (eds.) The Cynics: The Cynic Movement in Antiquity and Its Legacy (Berkeley: University of California Press, 1996); M. Goulet-Cazé, Les Kynica du stö̈cisme (Stuttgart: Franz Steiner Verlag, 1993). On performance and rhetoric, see D. Nikulin, 'Diogenes the Comic, or How to Tell the Truth 
end I will focus specifically on what appears to be contradictory and ambiguous about Diogenes, and indeed from Diogenes, and show how these contradictions are in fact instrumental to his Cynicism seen as a social and critical project.

I will argue that Diogenes' Cynicism can and should be understood as immanent social critique for the sake of the potential transvaluation of our norms. Such a critique is not in the manner of Socrates, Plato, Aristotle, et al., but stands as a different form of public praxis. I use 'immanent' here because Diogenes does not refer us to an ideal form, rely on a strict definition of virtue, or an external paradigm as such, but rather uncovers hypocrisy and problematic norms in situ, as he finds them within a social context. ${ }^{8}$ The intended effect of Diogenes' praxis, on my reading, is to reveal to the polity problematic norms. The critique is internal to its social context: religion in Athens, decorum in the marketplace, etc. He alerts the polity to the possibility of transvaluation by making visible the contingent nature of our moral values and social practices. By visible, I mean that the acts and antics of the Cynic convey meaning and show an alternative path, over and above discourse alone. If I am right, the view that Diogenes was merely anti-statist, a strict naturalist, a simple eudaemonist, or an austere individualist, will seem insufficient to explain early Cynicism and Diogenes.

In this paper I plot the following trajectory making four claims that support this view. First, I look at the classical debate about the nature of Cynicism and argue that Diogenes can best be understood as a philosopher of praxis. Second, I build upon recent views that Diogenes is a fictionalized figure to show how his persona is utilized to convey a social and political critique. Third, I argue that Diogenes' philosophical mission is not primarily to mint other Cynics in his image, following his example as a demonstration of particular 'Cynic'

in the Face of a Tyrant', in Arruzza and Nikulin (eds.), Philosophy and Political Power in Antiquity, Studies in Moral Philosophy 10 (Leiden; Boston: Brill, 2016), pp 114-133; P. Bosman, 'Selling Cynicism: The Pragmatics of Diogenes' Comic Performances', Classical Quarterly ${ }_{5} 6$ (2006), pp. 93-104.

8 Diogenes can sometimes refer to what appears to be an external reference, for instance, Spartan hardiness and strength. This may be understood as an external reference for virtue, but on my account, this reference is intended to juxtapose different norms (Athenian softness with Spartan hardiness) and not to idealize one norm even if Spartan hardiness aligns with Cynic presentation of resilience and strength. See Diog. Laert. 6.32; 6.27; 6.59; and especially Stob. Flor. 3.13.43, where Diogenes claims to be interested in dwelling with the Athenian sick rather than the healthy Spartans in order to improve their health. The emphasis on his intentions to improve the Athenian health is central to my reading of Diogenes' philosophical praxis. 
values, but to alert the public to the dynamics of contradictory aspects of polis life. And fourth I claim that Diogenes' praxis should be understood as a serious performance of immanent social critique. That is, Diogenes' praxis performs a critique internal to a social and political context, and not by endorsing wholesale an external universal or a determined standard.

\section{Overcoming the Classical Debate}

Cynicism was already a subject of dispute in antiquity. Was it best understood as a school of philosophy or a way of life? ${ }^{9}$ The difference separated those who saw Diogenes as a philosopher from those who saw Cynicism as a countercultural lifestyle. On the one hand, how was Diogenes a proper philosopher lacking a clear-cut Cynic theory like the theory of forms, or defined doctrine, like Aristotle's doctrine of the mean? And on the other hand, how does the Cynic way of life do justice to Diogenes' endorsement of reason and the importance of philosophy in the anecdotes? ${ }^{10}$ I believe a different emphasis is warranted. The question should be posed in the following way: are the aspects of Diogenes' way of life, his performances of wit and contrarian behavior, consistent with a view of Diogenes as a philosopher? If so, how? Understanding Diogenes' Cynicism need not simply be a matter of settling the debate between a way of life and the use of reason (or some amount of both), but rather understanding the essential interaction of the two.

Ancient accounts of Cynicism, including important works from Epictetus, Maximus, and Julian, paint an idealized, often Stoic-influenced portrait of Diogenes and his legacy. ${ }^{11}$ In general, they valorize the Cynic as one committed to promoting the true virtue of independence (autarchia) and dispelling false virtues like wealth and dependency, while shameless cynic behavior

9 Diog. Laert. 6.103: 'We will also set down the doctrines they held in common, since we distinguish that Cynicism is also a school of philosophy, and not, as others say, merely a way of life'. Translations (amended where indicated) are from Diogenes Laertius Lives of the Eminent Philosophers, J. Miller (ed.) and P. Mensch (trans.) (New York: Oxford University Press, 2018). Diogenes Laertius alerts the reader to the fact that some maintain Cynicism to be a way of life, others a philosophy. However, it is clear that Diogenes Laertius agrees with the latter.

$10 \quad$ Diog. Laert. $6.24 ; 6.37 ; 6.38 ; 6.56 ; 6.58 ; 6.73$.

11 M. Billerbeck, 'The Ideal Cynic from Epictetus to Julian', in Branham and Goulet-Cazé. pp. 205-221. 
is downplayed or even glossed over. ${ }^{12}$ If and when shameless or contrarian behavior is discussed, it is often attributed to cynic charlatanism. ${ }^{13}$ In this way, many of the ancient accounts of Diogenes as a model philosopher suffer from bias and cherry picking. Nevertheless, most of the ancient accounts are in agreement that Diogenes was a philosopher rather than merely an apostle for a way of life. ${ }^{14}$

The Cynic way of life had enough traction in antiquity to warrant Diogenes Laertius' comment about the existence of the debate, as well as the attestations about the Cynics seen as rabble from Epictetus, Lucian, Julian, and others. The Cynic way of life was much derided by these authors and they lambasted their activity as the cheap antics of false Cynics who took up style without substance. Epictetus tells us:

I fear we don't appreciate its [cynicism's] grandeur, nor do we have a fair idea of Diogenes' character. We are influenced by the sad spectacle of today's Cynics, these dogs who beg at the table and hang about the gate who have nothing in common with the Cynics of old except maybe for farting in public, not much else. ${ }^{15}$

Arr. Epict. Diss. 3.22

Many did take up the Cynic's double cloak, and many did act with the seemingly requisite shamelessness, but growing a beard or public flatulence does not a Cynic philosopher make. Epictetus may be right to admonish those who claim to be Cynics of his day as lazy characters who do not engage in the

12 Epictetus casts Diogenes as a divine scout promoting the true good, a stalwart exemplar of embracing hardship and espousing the virtue of freedom (Arr. Epict. Diss. 3.22); Maximus of Tyre (abbreviated here as 'Max.') mythologizes Diogenes as a man of the Golden Age out of place in the current ostensibly iron age of mankind (Max. Or. 36); Julian casts Diogenes with Socrates as an inspired true rational agent embracing the twin oracular calls to 'know thyself' and 'Deface the currency' in both word and deed. Julian attacks the would-be cynic who embraces a capricious costume of shamelessness rather than the primary motivation of the cynic: reason (Julian. Or. 6).

13 See Julian. Or. 3; Arr. Epict. Diss. 3.26; Max. Or. 3.

14 Julian. Or. 6 is quite clear that the mere costume and way of life are insufficient for the true cynic. What is needed, rather, is philosophical reason as mandated from the Pythian oracle and embraced by Socrates and Diogenes.

15 Epictetus Discourses and Selected Writings, R. Dobbin (trans.) (London, Penguin Classics 2008). 
grandeur of Diogenes, but he also seems to dismiss the farting, shitting, and masturbating of Diogenes as unrelated to his philosophical purpose. ${ }^{16}$

It is likely that some Stoic influence helped mythologized its own Stoic foundation by claiming to be true heirs of Socrates, albeit typically through Diogenes and Zeno of Citium, and not through Plato and the Academy. And it is this desire to be the true heirs of Socrates that I believe is somewhat to blame for excising the philosophical importance of shamelessness from Diogenes. This is because it appears to run counter to the kind of sober reason and decorum that informs the later followers of the Stoic tradition. ${ }^{17}$ After all, Diogenes does claim that reason, logos, is necessary: 'He [Diogenes] often remarked that to get through life one needed logos or a noose' (Diog. Laert. 6.24). To focus on this endorsement of reason is noteworthy, not because Diogenes can be seen to be akin to Plato or Aristotle elevating reason as most divine and heralding a contemplative or idealized order, but because reason drives Diogenes' antics and his countercultural provocations.

The emphasis on logos or reason is also a strong indicator against reading Diogenes as a brute or mere naturalist, but advocating for acting kata phusin, which for the anthropos - what Diogenes famously seeks with his lantern surely includes the use of human reason. One might suspect that the Cynic recommends merely wild or even animalistic behavior when he endorses acting according to nature, but this would be rash. For one, it is by the use of reason that the endorsement of nature can be made. And for another, reason need not be understood exclusively as a virtue opposed to wild or animalistic behavior. Rather, it is custom (nomos) that is typically opposed to nature (phusis). So we might consider how reason as a part of our nature can be opposed to custom,

16 Julian. Or. 6.202b reports Diogenes' public improprieties and bodily noises. See also D. Krueger, 'The Bawdy and Society', in Branham and Goulet-Cazé (eds.), pp. 225-229. Cynic flatulence is a topic of great interest and importance. For instance, Metrocles, the brother of Hipparchia, farted while going over a speech and was so mortified that he then attempted to starve himself to death. Unable to convince him by any argument that he had done nothing wrong, Crates could only dispel Metrocles' embarrassment by eating lupins and farting himself. Pace Critchley, hot air expelled from below is nothing to worry about compared with hot air that comes from the other end. S. Critchley, The Book of Dead Philosophers (New York: Vintage Books, 2008), p. 29.

17 Socrates, as depicted in the Platonic corpus, was not immune to the charge of shamelessness, although his actions hardly approach Diogenes' doggishness. Consider Socrates' three waves (Pl. Resp. 5.452a ff.), where the proposal of women and children in common aligns with suspected views about Diogenes' own proposals in his Republic. See also J. Moles, 'Cynic Cosmopolitanism', in Branham and Goulet-Cazé (eds) pp. 105-120; J. Sellars, 'Stoic Cosmopolitanism and Zeno's Republic', History of Political Thought 28 (2007), pp. 1-29. 
as Diogenes' antics seem to show generally. Diogenes' lantern, in this way, can be understood as seeking to find a human who by nature has reason. To be sure, one may have the natural capacity for reason without employing it. ${ }^{18}$

In several well-known places, Diogenes speaks about his care for philosophy. ${ }^{19}$ One account appears to downplay his endorsement of reason, but it can also show the opposite. Diogenes Laertius: "To someone who said, "Though you know nothing, you philosophize", he [Diogenes] replied, "Even if I do pretend to have wisdom, that in itself is philosophizing"' (Diog. Laert. 6.64). On the face of it, this report could be mistaken to attack Diogenes' fraudulence because he readily admits to 'pretend to wisdom'. But this is only the surface of the claim, which is remarkable in at least two further ways: First, the charge of knowing nothing may be a shallow attack on Diogenes, but it is also positively charged with Socratic irony, where the 'knowing' (eidōs) can be a wink towards Socrates. Second, the wordplay is reflective of the philosophical cleverness of Diogenes who rebuffs the challenge, richly claiming that pretending to have wisdom is to philosophize, suggesting that wisdom as an ideal or acquisition might be problematic. The reply knowingly adopts the trope of Socratic ignorance, including all of the philosophical merit of that tradition.

Diogenes adopts many facets of Socrates including his dialogical and ethical inquiry, public discourse, and simple dress. But moreover, his response to the charge of ignorance is more philosophically informed, particularly because I believe that Diogenes raises nominalist objections to universals; he argues against the ideal realm of the forms, and certainly against knowledge of the forms, so pretending to have 'wisdom' is in one sense all one can have, if wisdom is to know unchanging truths. So, his response can be interpreted to affirm his Socratic inquiry relative to wisdom but reject the Platonic forms. Diogenes rather exposes contradictions in a way that opens up social practices to public awareness, scrutiny, and examination; he eschews univocal, external, and universal standards as he rejects forms. Therefore, he restricts knowledge and wisdom, in this particular sense, to the realm of inquiry and opinion, where wisdom is dialectical rather than univocal, ideal, and external. A good example is illustrated in the following passage:

18 For instance, see Diog. Laert. 6.27 where Diogenes makes the point that the public ignores him when he discourses on serious matters, but when he makes a spectacle of himself and whistles nonsense, the public takes serious note.

19 See Diog. Laert. 6.36 where Diogenes confronts followers who wish to learn philosophy; Diog. Laert. 6.58 where Diogenes praises a youth for beautifying his mind through philosophical study; Diog. Laert. 6.70-71 where Diogenes urges the training of the mind. 
When Plato was conversing about the forms, and using the words 'tablehood' and 'cuphood,' Diogenes said, 'For my part, Plato, I can see a table and a cup, but not tablehood and cuphood,' to which Plato replied, 'And that makes sense; since you have the eyes with which to see a cup and a table, but not the mind with which to comprehend tablehood and cuphood.' ${ }^{20}$

Diog. Laert. 6.53

The inability to have 'a mind with which to comprehend tablehood and cuphood' sounds like Plato has the upper hand here, but this would be a hasty inference. Diogenes' statement is consistent with a nominalist objection to the use of abstract forms because they offer a univocal universalist standard of understanding, one which Diogenes challenges in favor of what I call a dialectical praxis, or making oppositions visible in speech and action. This view will be taken up later in section 4. Secondly, Diogenes clearly defends the benefits of reason and philosophy, here as elsewhere, supporting his quip 'logos or a noose'. He defends philosophy in the face of the attack that he lacks wisdom, turning the attack into an affirmation of the kind of philosophical commitments that he holds dear: philosophy helps cultivate character and reason guides our actions. ${ }^{21}$

Diogenes not only attacked the viability of Plato's notion of forms but also the conclusions funded by his method of division (diairesis) leading to the infamous incident of the plucked cock in the Academy. As the story goes, Plato defined the human as a featherless biped based on his method of division, which intended to help teach students to identify forms. The definition reached by Plato was lauded: 'Plato defined Man as a featherless biped animal and was cheered' (Diog. Laert. 6.40). Such adulation suggests that Plato's audience was impressed with the divisions and the conclusion.

Diogenes refutes Plato's definition of 'human' not by engaging in an argument, but by deploying a contradiction in action, in this case, throwing a

20 Diogenes Laertius. Lives of the Eminent Philosophers (P. Mensch trans.) (New York, Oxford University Press 2018). Translation amended.

21 Diogenes recommends exercise not only for the body but importantly for the soul ( $p s y c h \bar{e})$ where exercise includes reason (Diog. Laert. 6.70; 6.71). Other examples include G. Giannantoni (ed.) VH 106 = A. Malherbe (ed.): Crates 19.24: Crates speaks of Odysseus as an example for a Cynic, saying 'he trusted in reason and not in guile or bow ...'; Giannantoni vH108 = Malherbe: Crates 21 also exhorts the use of logos; See also Giannantoni vH108 = Malherbe Diogenes 21.11; Giannantoni vв 545; and Malherbe Diogenes 15.6: 'For not only is it necessary that the body exercise this simplicity, but the soul ( $p s y c h \bar{e})$ should too, along with it. That is to say, it should not promise much and do what is not sufficient, but should demonstrate that reason (logos) attends to the way of life' (Fiore (trans.), amended). 
plucked cock into the Academy and calling it Plato's anthrōpos. ${ }^{22}$ Diogenes' cleverness in using a real featherless biped, using the physical embodiment for what otherwise is restricted to a thought experiment, not only rebukes Plato but affirms Diogenes' employment of nominalist positions. The featherless biped is simply that. One can only imagine Plato's audience approving the show, but the rebuke of Plato makes his definition of man as a thought experiment suspect because it casts those who would engage in abstract philosophical diairesis as out of touch with reality. In fact, challenging Plato's definition of 'human' may even indicate Diogenes' knowledge of Plato's method of division from the complicated Politicus, where the origin of this definition of the anthrōpos resides, once again affirming Diogenes' philosophical bona fides. ${ }^{23}$

So, it is clear that Diogenes defends philosophy with an understanding of Plato, showing his cleverness in the anecdotes that challenge Plato's politics, vanity, and wealth. ${ }^{24}$ In doing so, he demonstrates a sharpness that aligns with his endorsement of the value of reason, but the use of reason need not include abstract universal concepts. He even admonishes those who would make a pretense to study philosophy but lack the commitments required. In fact, he makes an example out of potential pupils who would abandon the pursuit of philosophy over the perceived indignity of carrying around a fish in public or a potentially odiferous slab of cheese (Diog. Laert. 6.36). As if proving a point to his potential students, Diogenes held up a fish during a speech by Anaximenes, distracting him from his lecture. This action demonstrated that embarrassment or indignity from a fish is unnecessary. In addition, such embarrassment is indicative of one who cares too much for the social conventions that define decorum and not enough about reason, which can help dispel problematic norms that have been sedimented into unreflective social action. Blushing, for instance, should be considered a badge of honor. 'One day, seeing a youth blushing, he said, "Cheer up! Yours is the complexion of virtue"' (Diog. Laert. 6.54). The point is not to overcome our emotions and sense of shame full stop. Rather, Diogenes' point seems to be to recognize that embarrassment is driven by convention, and the blush is indicative of breaking convention cheer up. Diogenes' endorsement of embarrassment should not be understood

22 See Sluiter, 'Communicating Cynicism: Diogenes' Gangsta Rap' for a strong reading of Diogenes' non-verbal performance of refutation.

23 Pl. Plt 266e7. The Eleatic Stranger and the young Socrates demonstrate 'cutting at the joints' through diairesis to hit upon forms and define 'man' as 'featherless biped.' There is a joke upon a joke here as the definition is not intended to be definitive but instructively humorous in the Politicus. See M. Miller, The Philosopher in Plato's Statesman (Las Vegas: Parmenides Publishing, 2004), p. 28. 
as a sign that all conventions must be broken, but that embarrassment can be used to shine a light on our norms.

Although Diogenes demands respect for logos, a more comprehensive account of Diogenes ought to also include the intentional wildness and 'doggish' nature of the philosopher, particularly because he also self-identifies as a dog: 'Once when Alexander came to him and said, "I am Alexander, the Great King," he replied, "And I am Diogenes, the Dog"' (Diog. Laert. 6.6o). Speaking to this issue, recent scholarship has in fact examined important theatrical and comedic components of Diogenes' khreiai, for instance, utilizing the tactics of comic theater and satire (Bosman), and employing both vocal and non-vocal performance aspects (Branham, Sluiter) ${ }^{25}$ Diogenes does perform in a manner that is well described as comedic, and his double aspect of being both comedic and serious suggests an apt reflection on the notion of spoudogeloion, ${ }^{26}$ the combination of the serious and laughable. While scholars have identified the comedic value of these anecdotes and the power of Cynic wit, the focus on the political implications have remained somewhat underserved.

So far, so good. Diogenes should indeed be considered as a philosopher, and in this sense the admirers from antiquity are quite correct. But the shameless antics that are sometimes elided can and should be understood as an essential part of Diogenes' philosophical praxis and of his didactic efficacy, and not relegated merely to cynic charlatanism or performance theory. This is particularly important when the anecdotes disclose performances of unexpected sometimes paradoxical behavior. For instance, Diogenes wished to be buried face down, entered the theater when the crowds were rushing out, tried to rid himself of material possessions instead of amassing them, performed private acts in public, etc.

Diogenes' anecdotes give light to essential oppositions, most famously of nature and custom. And the shameless actions make these contradictions and oppositions quite visible to the public.

He regularly performed in public the acts associated with Demeter and Aphrodife. He used to make the following sort of argument: If to take breakfast is not absurd, then in the marketplace it's not absurd; and it is not absurd to take breakfast; so to do so in the agora is not absurd.

25 Bosman 'Selling Cynicism: The Pragmatics of Diogenes' Comic Performances', p. 93 ff.; Sluiter 'Communicating Cynicism', p. 140 ff.; R. Branham, 'Defacing the Currency: Diogenes' Rhetoric and the Invention of Cynicism', In Branham and Goulet-Cazé (eds). pp. 81-104.

26 H. Gärtner, 'Spoudogéloion', Brill's New Pauly, H. Cancik and H. Schneider (eds.) Brill's New Pauly, Brill Reference Online. Web. o4 October $2021<$ http://dx.doi.org/10.1163/1574 -9347_bnp_e1120210>. 
Frequently masturbating in public, he said, 'If only one could relieve hunger by rubbing one's belly' ${ }^{27}$

Diog. Laert. 6.69

A few points on this passage: First, when the Cynic is seen as shameless for his acts, the polity is given the opportunity to consider why such actions are a source of shame. Diogenes may have at his disposal the argument that acting in accord with our nature (and therefore eating, farting, sex, and the like) ought not be immediately dismissed as a source for shame, but the anecdotes first prioritize reporting his actions, emphasizing the demonstration of seemingly shameful acts. ${ }^{28}$ Secondly, when Diogenes employs argumentation, it is typically in defense of the acts already performed. In conjunction with his unseemliness in the Agora, Diogenes' use of syllogism underscores his employment of reason, even if it is deployed in a satirical manner.

Finally, the example of masturbation, which I believe is juxtaposed to eating in the Agora by virtue of its adjacent placement, is shameless insofar as it exposes the contrast of nature (our natural human desires) in the context of public decorum. It promotes the idea of independence and self-sufficiency, but it does so by making overly visible the contrast with what is socially acceptable and the natural aspects of the body. Diogenes Laertius even makes the point that Demeter and Aphrodite approve, if not even endorse his shameless act, rendering sex and masturbation a divine-like activity that need not require syllogistic rationalization.

Nevertheless, this anecdote also makes another point. In drawing attention to self-gratification in the agora, we are confronted with the fact that Diogenes had just argued that it was absurd to bar eating in the market. Diogenes' reply, that 'if one could relieve hunger by rubbing one's belly' is not merely a profane wink, but also responding to the fact that he is hungry whilst surrounded by food in the marketplace. Ought we be able to relieve hunger as easily? In this light, the proper shame might belong to Athens, whose bounty of food sometimes leaves Diogenes without. At the very least, Diogenes makes it clear that there are limits to independence and self-sufficiency, and on this reading, the Cynic makes it known that staving off hunger is not entirely up to the individual, declawing the anti-state individualist view of Diogenes. Moreover, the limits to independence and self-sufficiency deflate the view that the Cynic proclaims freedom or self-sufficiency to be a virtue without contending with

27 Mensch trans., (2018). Translation amended.

28 Diogenes sometimes employs syllogism, for instance at Diog. Laert. 6.72, where he funds the rational basis for eating in the agora while making a mockery of syllogistic style. 
the delimiting constraints of its opposite. Because freedom or self-sufficiency might otherwise be seen as a Cynic universal claim, Diogenes' performance rebuffs this by making clear that dependency is part of self-sufficiency in the agora anecdote. ${ }^{29}$

This method of illuminating oppositions is Diogenes' public philosophical praxis: he chooses direct engagement with the public, rather than to display his philosophical views in a more traditional way as a philosophical orator, or as an exemplar of anti-state and naturalist behavior, both of which have limited efficacy. The traditional forms of philosophical oratory are limited because they can cleave off philosophical engagement in the public space, preferring instead the restricted confines of places like the Academy and Lyceum, and mere anti-state radical behavior, taken for its own sake, is uninformed pseudoCynicism like those reported by Epictetus.

Where direct public engagement might require less sophisticated and subtle forms of communication, the effect of shameless praxis can inform social critical awareness from the bottom up, not restricted to the education of the more elite. ${ }^{30}$ If Diogenes' philosophical praxis is for the sake of potential social and political transformation, as I propose, the question remains not only how might transformation occur from Cynic provocation, but also to what end? But if Diogenes Laertius is an unreliable source, the anecdotes are tall tales, the source material from Diogenes' time is unavailable, is my notion of Cynic social critique unfounded? When all is said and done, is all of this merely a pseudo philosophical fiction?

Diogenes is a transformational character. His exile and subsequent philosophical awakening attest to his transformation from Sinopean to Cynic. While it may be true that the circumstances of Diogenes exile helped Diogenes to become the Cynic philosopher, Diogenes is essentially a product of fictionalization, even intentional fictionalization. His famed exile, for instance, becomes central to his own narrative: 'To someone who had reproached him for being an exile, he said, "But it's thanks to that, you fool, that I became a philosopher"' (Diog. Laert. 6.49). This removal from Sinope is part of Diogenes' philosophical

29 See J. Mansfeld, 'Review of "L'Ascèse Cynique. Un commentaire de Diogène Laërce, vi. 70-71 by Marie-Odile Goulet-Cazé", Classical Review 38 (1988), p. 163.

3o P. Bosman, 'Ancient Cynicism: For the elite or for the masses?', in R. Evans, (ed.), Mass and Elite in Antiquity' (London: Routledge, 2017), pp. 34-48. 
autobiography and his exile from the polis is recast as the liberation from civic custom. Defacing the currency (nomisma), his credo and crime, makes use of the doubleness of the Greek for 'currency' which derives from nomos, both law and custom (Diog. Laert. 6.21). The ambiguity of 'currency' allows for the revision of his act of defiance to an act of liberation and gives rise to Diogenes' character as a fictionalized philosophical provocateur.

Diogenes' actual history, I propose, is not as significant as the canonized anecdotes. If he actually vandalized coins in Sinope or personally affronted Alexander, such facts as facts are not fundamental to understanding Cynicism. The history of Diogenes is conflicted about some matters. For example, there is no consensus concerning whether Diogenes or his father actually chiselmarked the coins that led to his exile (Diog. Laert. 6.20). On the other hand, the almost mythological rather than verifiable nature of the anecdotes confront us as if they are a record of Diogenes' life without the need for verification. ${ }^{31}$

Branham and Sluiter, for instance, rightly insist that Diogenes is a 'novelized' figure. ${ }^{32}$ And to be sure, Diogenes also inspired fictional representations in many forms. His legacy in antiquity includes anecdotes, satires, letters, and orations from Dio Chrysostom, Epictetus, Lucian, Maximus, and Julian, to mention only a few. Diogenes is also the subject of literature that inspired Enlightenment thinkers such as Rousseau, and so-called post-modern thinkers like Foucault.. ${ }^{33}$ But Diogenes' persona is more philosophical than mere fictionalization would attest, and it is certainly more provocative than his verifiable biography. This is because his crafted persona is the conveyance of his provocations. ${ }^{34}$

If Diogenes did deface the coins, the physical act of defacing the coins and the figurative meaning are still not the same, the former being an act of political rebellion or vandalism, and the later as a credo and the valorization of a divine calling:

Some say that having been appointed to oversee the workmen, he was persuaded by them, and that he went to Delphi or to the Delian oracle in his own city and inquired of Apollo whether he should do what he was urged to do. When the god gave him permission to alter the political currency, not understanding what this meant, he adulterated the coins, and

31 Consider, for instance, the ideological principle of New Criticism which eschews the use of biography for any valid hermeneutic understanding of poetry.

32 Sluiter, 'Communicating Cynicism' p. 141 ff.; Branham, 'Defacing the Currency' p. 86; also M. Bakhtin, The Dialogic Imagination, (Texas: University of Texas Press, 1983), p. 38.

33 Shea, 'The Cynic Enlightenment', pp. 169-191.

34 Branham, 'Defacing the Currency', p. 87; Sluiter, 'Communicating Cynicism', p. $141 \mathrm{ff}$. 
when he was detected, according to some he was exiled, while according to others he voluntarily left the city for fear of consequences. One version is that his father entrusted him with the money and that he defaced it, in consequence of which the father was imprisoned and died, while the son fled, came to Delphi, and inquired, not whether he should re-stamp the coinage, but what he should do to gain the greatest reputation; and that then it was that he received the oracle. ${ }^{35}$

Diog. Laert. 6.20-6.21

Diogenes misunderstood the divine advice to deface the coins, realizing and adopting the figurative value of the message only later. ${ }^{36}$ One account has Diogenes deface the currency having mistaken the alteration of political coinage with actual defacing, overlooking at first that 'political coinage' (to politikon nomisma) also means 'political custom'. This etiology reinforces the view that Diogenes transformed himself, reconsidering his act of vandalism as a divine calling from the double aspect of 'coinage'. In the second account, Diogenes inquired about re-stamping the coins, having already defaced them. This could mean to re-establish the original legitimacy of the altered coins to save face, or to revaluate the coins in a new way. He chooses to challenge the political norms, revising his initial act of vandalism here as well. Both accounts show Diogenes reevaluating the coin from state sanctioned silver to the liberating act of revaluing political normativity; both suggest that the transformation from vandal to Cynic philosopher runs parallel to the reconsideration of 'coinage'.

The revaluation of defacing is a prime example of Cynic transformation. And because Diogenes seemingly adopts 'defacing' as a credo for Cynic activity, it is a prime example of an intentionally crafted persona. In other words, by recasting his exile as divinely sanctioned, and the 'currency' from 'coin' to 'custom,' Diogenes transformed into a fictionalized (i.e., self-crafted, or even a self-mythologized) persona, namely, a divinely inspired countercultural agent. This example of transformation is a key to understanding how Diogenes' didacticism functions, so let us take a closer look.

Diogenes' persona is fictionalized, which subverts as much as possible being swept up in the socio and ideological status quo, makes himself relatively immune to culpability and in order to make visible problematic normative

35 Diogenes Laertius Lives of Eminent Philosophers (R. Hicks trans.) (London, Harvard University Press, 1925). Translation amended.

36 The transformation from literal meaning to figurative meaning with respect to the oracular advice is mimicked in the persona of Diogenes as a philosopher. The figurative meaning speaks over the literal meaning. 
practices. The oracular endorsement of Diogenes, paralleling the oracular endorsement of Socrates, also supersedes the negative aspect of his exile. It juxtaposes the divine calling of the philosopher with the everyday affairs of public and political life, wealth, rank, and all the rest of what the Cynics call 'smoke' (tuphos) or false virtues (Diog. Laert. 6.26). Exile from Sinope is what makes him a philosopher, both through the divine endorsement and its concomitant characteristics of a divinely inspired philosopher, and the otherness that he embodies, being exiled or self-exiling himself form social and civic normativity, to the extent that he can, in order to illuminate the tuphos of problematic nomoi.

Diogenes' characterization as an exile is in this way instrumental to his challenge to society. His exile from the customs of polis life makes possible the appearance to be radically out of place without overly threatening the social order. Fictionalization makes Diogenes a legend or a myth in his own time, in his own way, allowing the Cynic to subvert the social norms as a philosophical artist rather than a mere dissident. Maximus, for instance, underlines Diogenes' otherness not as an artist, but his exteriority, suggesting that he is out of his time period - he is a golden age figure who lives in the age of iron. ${ }^{37}$ His wild and shameless praxis functions as performative critique, exhibiting that normative social action can be otherwise.

By adopting a persona that is in 'exile,' not from a particular city, but somehow exiled and therefor free from the confines of convention itself, he is able to demonstrate what otherwise would seem completely objectionable. And while he appears to be outside of the social structure, this is only to the extent that makes visible the normativity of social conventions that otherwise would remain hidden in the polity. To be sure, Diogenes is not exempt from the necessity of culture and coin, even if they are contingent; he lives on the margins of society and not in mere 'nature'. Diogenes, after all is called a dog and not a wolf. ${ }^{38}$ Diogenes needs the polis for food, for shelter, and for an audience, but appears to be outside of the society in a way that can make convention visible as such.

Because Diogenes cannot revert to life, as it were, in the wild, the opposition of mere nature and nomos is not mutually exclusive, nor is phusis to be seen as referring to wildness outside of the polis. Rather phusis and nomos are what Diogenes shows to be in opposition, even if they are both necessary aspects of bios. To be sure, Diogenes necessarily makes use of custom himself: he still dons a cloak even if it is doubled over; he still carries a stick and wallet; and he

37 Max. Diss 6; Max. Or. 36.

38 Nikulin, 'Diogenes the Comic, or How to Tell the Truth in the Face of a Tyrant', p. 118. 
accepts invitations to banquets when offered (Diog. Laert. 6.32). For this reason, the act of defacing ought to be understood as imminent critique based on the recognition of the duality and often divergent pull of our nature and custom within society; our nature is often unnecessarily constrained by custom, following unnecessary rules of social decorum. Diogenes' self-exile is utilized to illuminate the duality of being both outside of convention but not entirely outside of society. And this almost impossible burden of normative self-exile, one that the Cynic calls toil (ponos) ${ }^{39}$ that is concomitant with the credo of 'defacing the currency' can most successfully be shouldered by Diogenes as a persona, even if the historical Diogenes was in fact booted out of Sinope for numismatic fraud. The challenge to the polity from Diogenes is not simply to come to terms with the juxtapositions and oppositions he illuminates, but to understand the relationship between the pairs, and to potentially overcome the ill effects of over-allegiance to unreflectively followed customs.

The possibility of Cynic transformation is tied up with Diogenes' didacticism. Since it has been argued that Diogenes is a missionary figure, it is possible to consider his actions as a model for Cynic behavior. ${ }^{40}$ But I believe this viewpoint is misleading. I will argue here that Diogenes is best understood as a didactic and provocative figure, and merely copying his actions misses the substance of his Cynicism, even if he had disciples and followers.

If Diogenes is a missionary figure, what would an ideal community of followers look like? Could we conceive of a community of Cynics intent on throwing off traditional notions of work and defying all manners of decorum? He may have envisioned a community of Cynics in the now lost Republic. And although it is lost, it has been argued that one can reconstruct the salient features of his Republic from the evidence that remains, for instance, from reports about Zeno's Republic and from comments from Philodemus. ${ }^{41}$ The text argued, for instance, for women and children to be held in common, education to be

39 Diog. Laert. 6.71.1: Ponos, Cynic toil, which is according to our nature, kata phusin, refers to the exercises that help not only strengthen the body and guide our actions, but by virtue of our human soul rather than animality. In this way, the image of Herakles who has amazing strength aligns with Diogenes' endorsement of the value of toil kata phusin over the value of nomos (Diog. Laert. 6.71.7).

40 J. Moles, 'Honestius Quam Ambitiosius? An Exploration of the Cynic's Attitude to Moral Corruption in His Fellow Men', Journal of Hellenic Studies 103 (1993), pp. 103-123.

41 Shea, The Cynic Enlightenment, pp. 81-82. 
reformed, currency abolished, and incest and cannibalism to be acceptable. ${ }^{42}$ A community of Cynics, however, would not unproblematically follow from the interpretations that cast Diogenes as one who promoted a doctrine of austere individualism or anti-statism because a politeia in fact is collective. Nevertheless, there is insufficient evidence to claim that Diogenes envisioned a defined universal standard or an idealized Cynic utopia, particularly because the features ascribed to his Republic could easily be Cynic provocation.

Diogenes, again, can appear to promote a value in accord with nature, 'he assigned to custom none of the that which he assigned to nature (kata phusin)' (Diog. Laert. 6.71), ${ }^{43}$ so it is worth further asking what this means. Does Diogenes claim that custom is completely without value? Nature could refer to living outside of norms and civic custom, and in this sense refers to a life seemingly outside of a polis. In fact, Diogenes famously claimed that he was kosmopolitēs, belonging to the world. 'Asked where he came from, he said, "I'm a world-citizen"' (Diog. Laert. 6.63). Following this line, 'cosmopolitanism' would be a negative claim signifying that he does not live in any polis as such. Such a reading supports the interpretation of Diogenes as anti-state and endorsing strict naturalism. In rejecting the polis, he appears to endorse a more 'natural' world, but this would be a hasty conclusion that overlooks two essential points: First, the natural reading of kata phusin is not mere wildness but according to our (human) nature, and second, it overlooks the necessities that come from the city and custom. For even in the claim to re-stamp the custom and coin, there must be underlying metal to reform, in this case, custom from the polis.

To be sure Diogenes often acts as a dog to make his point, but not because we should all aspire to be dogs. The wildness can and should be seen as provocation that is not simply a demonstration of the virtue of living strictly kata phusin. The anti-state naturalism view overlooks Diogenes' ready use of the polis. At a minimum, Diogenes uses the polis for food if not for his audience, as we see in the agora masturbation story, and nomos is constitutive of the polis. So both phusis and nomos are operative here for Diogenes, even if they are opposed and constrain each other.

Just because Diogenes does not assign the same devotion to nomos as he does to phusis does not require that they are mutually exclusive or that there

42 J. Sellars, 'Stoic Cosmopolitanism and Zeno's "Republic", History of Political Thought, 28 (2007), pp. 8-11; Diog. Laert. 7.32-33.

43 Sellars, 'Stoic Cosmopolitanism and Zeno's Republic', p. 6; Diog. Laert. 6.71. The Greek

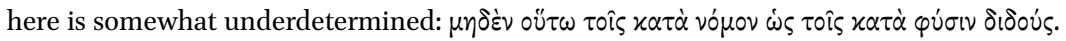
There is no need to read the sentence as saying that Diogenes gave no value to nomos, only that Diogenes did not assign to nomos that which he assigned to phusis. 
is no value to nomos whatsoever. He does not fully reject the polis in favor of strict naturalness, in fact he requires some aspects of the city. Some, if not most customs of the polis might require reconsideration and revision, but all custom cannot be expunged lest the polis and her citizens cease to be. Therefore, neither phusis nor nomos is a paradigmatic model on its own without its constraining opposite as a dyad. In this way the pairing is consistent with the view of Diogenes' praxis is a form of immanent critique, illuminating the dynamics of phusis and nomos without appealing to a fully determined model of behavior that is merely kata phusin to the exclusion of all custom.

So much for the claim that Cynic cosmopolitanism negates or excludes nomos and the polis. Cynic cosmopolitanism can be understood in another way. Diogenes is advocating for membership in the world in a way that does not restrict his also being a part of a polis, say, Athens or Corinth, in some necessary way. Because the world is home to all cities, it is a higher order category. John Moles quite rightly asserts that there is a paradox at work here. ${ }^{44} \mathrm{In}$ fact, I think that there are two challenges. First, it is absurd to think that a citizen or politēs is coextensive or symmetrical with the organizational elements of the cosmos. The citizen is defined by participation in the polis, and the polis is organized in virtue of the politēs. Not so with the kosmos. Kosmos can be understood to have order without politēs. Second, if Diogenes challenged the virtue of the polis (and therefore the virtue of citizens) on the basis of their dedication to false virtues, how could Diogenes in good faith claim to be any kind of politēs? Kosmos-Politēs is therefore self-contradictory in its own right, if kosmos refers to a natural ordering of the world and politēs a normative structure. The 'world' is not organized by nor determined by citizens in the way that the polis is. The later Stoic idea of cosmopolitanism and the idealization of a utopia of the mind misrepresents its original function - cosmopolitanism is a Cynic propaedeutical paradox. ${ }^{45}$

Diogenes places our nature in opposition to the customs and the laws of the polis, but it is possible to be inclusive about our nature and custom. Life

44 Moles, 'Honestius Quam Ambitiosius? An Exploration of the Cynic's Attitude to Moral Corruption in His Fellow Men', p. 110. See also D. Konstan, 'Cosmopolitan Traditions', in R. Balot (ed.), A Companion to Greek and Roman Political Thought. (West Sussex: Wiley-Blackwell Publishing, 2009), pp. 473-484.

45 Plutarch claims that Zeno's Republic endorsed one commonwealth for all, but that it was fulfilled in some sense by the project of Alexander who brought together all men, uniting them into a fatherland: 'He bade them all consider as their fatherland the whole inhabited earth, as their stronghold and protection his camp, as akin to them all good men, and as foreigners only the wicked.' Plut. Mor. 329b-c. Plutarch, Moralia Vol. 4. Babbitt (trans.) (London, Harvard University Press, 1936), pp. 396-399. 
kata phusin at its most basic is pervasive for us, and the polis might in some sense constrain some aspects of our nature in favor of collectivity and custom. As Diogenes would have it, the use of a drinking cup is a constraint on our natural ability to drink from our hands, and therefore Diogenes smashes his cup in favor of his hands to make this point visible (Diog. Laert. 6.37). Fair enough, but our nature is also a constraint on the polis. Custom demands that Diogenes should not sleep in the temples, eat in the agora, or defecate in public. But sleeping, eating, and defecating are natural human activities that the polis must accommodate rather than banish. In this way, the relationship of phusis and nomos, interconnected as they constrain each other, emerges from Diogenes. Therefore phusis once again cannot be taken as the ultimate guiding principle to the complete exclusion of nomos, and this means that one must try and understand the proper relationship between the two; this relationship is what Diogenes' praxis alerts his audience to, as imminent critique through public praxis.

One account of Diogenes' demise claims that he died from eating a raw octopus, showing that the artifice of cooking was in fact necessary even if a product of custom (Diog. Laert. 6.76). This dying act makes clear that a life kata phusin to the exclusion of custom might be absurd for humanity. If living life in accord with nature implies living like a non-human animal, the octopus incident makes it clear that there are limits that make this view ridiculous. And so we ought to be disabused of the notion that following Diogenes as a model would require understanding his actions representing anti-state individualism or mere naturalism, but rather Diogenes makes evident that there are dyadic oppositions at play in society that need to be contended with well. ${ }^{46}$

The paradoxes of 'cosmopolitanism' (the combination of the contradictory politēe and kosmos) show that Diogenes was not naive about the possibility of living outside of custom and law entirely, it is not entertained as an option by any of the anecdotes. 'Cosmopolitanism' nevertheless reveals to the alert and critical reader the interrelated way that nature and custom are inextricably bound to the human animal in a social context, even if they are also dialectically opposed. This is the prime case for Cynic praxis giving rise to our social norms defined by nomos. Why should we be ashamed of carrying a fish, public lewdness, or using the temples for sleeping? The Cynic in this way shines their

46 In general, making clear that social norms need critical reevaluation is a tried and true tradition following from Socrates and continued through many Hellenistic traditions, but what is unique about the Cynic performance on my view is that the critique comes through praxis, and is intended to effect the public in a more direct way. 
lantern illuminating the contingency rather than the necessity of particular norms, thus occasioning one to reconsider unreflective social conformity.

Diogenes Laertius also tells us that Diogenes described himself like a chorus director. 'He used to say he was imitating the chorus trainers; for they would set their pitch a little sharp so that everyone else would hit the right note' (Diog. Laert. 6.35). If a Cynic follower unreflectively attempted to sing like Diogenes, they would fall short of the high pitch, hitting instead the proper and less extreme mark. Second, the high pitch reflects the exaggerated way that Diogenes acts, making clear that the actions of Diogenes are instructive in a less direct way. The corrected pitch, as it were, is not so sharp as the wild antics of Diogenes would show us. If Cynic followers were to mimic Diogenes' actions as he performs them the results would be, so to speak, too high. Ought we to spit in the face of dinner hosts, walk against the crowds, even carry around a fish in order to be a Cynic? Or would this be a recipe for Epictetus' problematic false Cynic?

In guiding potential Cynic disciples, praxis is endorsed over philosophical doctrine. Therefore, we should see the Cynic disciple, to the extent possible, not simply as someone who adopts the views of a Cynic sage, but one who questions inherited values, exposes contradiction, and defaces the common currency taking up the practice of social critique.

\section{Cynic Praxis as Immanent Critique}

So far, I have claimed that Diogenes should be understood as a didactic figure: one whose actions should not be seen as a mere model to follow, but rather to make the polity alert to problematic contingent norms in political life. Insofar as Diogenes shines his lamp on the tension between contingent norms in contrast to more essential aspects kata phusin, his antics are in the service of a social critique, making visible the oppositions inherent in the social and political aspects of human life. But because Diogenes on my reading is against strict univocal paradigms, universal forms, or a predetermined ideal, the possibility of transvaluation arises from internal social critique without utilizing an external universal standard, or a defined and determined doctrine like living kata phusin to the exclusion of living kata nomon. Diogenes does not model ideal behavior but provokes a reconsideration of normative behavior, alerting us also to the interrelated way that these oppositions constrain each other and are dyadic and not mutually exclusive. This critique is fulfilled by Cynic praxis which makes visible the internal tensions and oppositions that otherwise recede into the common coin of everyday life in a polity. For this reason, 
Diogenes' Cynicism can best be understood as a performance of immanent critique. Let us take a closer look.

Diogenes presents himself as countercurrent, and this is displayed in a variety of anecdotes, but perhaps encapsulated succinctly in the following one: 'He was entering the theater as everyone else was leaving it; when asked why, he replied, "This has been my practice all my life"' (Diog. Laert. 6.64). The practice of going against traffic is central, but not because it demonstrates the best path to follow. Diogenes goes against the flow of normative behavior, and the practice of doing so exposes the fact that it is possible, and that our everyday social behavior tends toward conformity in an uncritical way; we walk with the crowd. The example of walking against the flow illustrates the general tactics of Cynic praxis, while leaving open the articulation of a particular normative structure that Diogenes might challenge other than participating in civic theater.

We might think that the primary internal opposition in polis life arises from the necessity of the interaction of our nature and custom, true enough, but there are other contradictions that are also made explicit. Diogenes is described as contrasting opposites more generally: 'He claimed that he set luck against courage, custom against nature, and emotion with reason' (Diog. Laert. 6.38). The emphasis on courage dispels mere dependence on luck, nature over blind convention, and so on. The duality of the pairings set up the possibility for a transvaluation of social and civic action, or an overcoming of traditional sedimented standards of political conformity. The point is not to suggest the mere virtue of life according to nature, courage, and reason, but the polarization of courage to luck, nature to custom, reason to emotion. As with the dual aspect of nature and custom which is inherent in polis life, courage and luck, reason and emotion, can likewise be understood as oppositions that constrain each other and are not mutually exclusive. The illumination of these oppositions alerts the polity to dynamics that can be reformed or re-stamped.

In the same way, Diogenes makes evident the complicated relationship of political power and freedom, exposing that the force of one is complicated by the dependence on the other: 'Menippus says in his Sale of Diogenes that when captured and put up for sale Diogenes was asked what he was good at. He replied, "Ruling over men," and said to the herald, "Spread the word in case anyone wants to buy himself a master"' (Diog. Laert. 6.29). The opposition of master and slave exposes the interrelated and dependent nature of the two. ${ }^{47}$

47 This is reminiscent of the Master and slave dialectic in Hegel's Phenomenology of Spirit. Although in my view Hegel mischaracterized Diogenes and Cynicism as being of little philosophical importance. Rightly assessed, Diogenes is a prime example of dialectical 
He claims that his skill is that of the ruler, that he is an archon, even though he is auctioned off as a slave. In doing so, he illuminates the master-slave interdependence and alerts us to the mutually dependent nature of kingship and subjects.

His biography, much like his self-determined exile, includes his sale into slavery. Diogenes Laertius reports that the sale of Diogenes was fulfilled when he was sold to Xeniades, a well-dressed rich and powerful Corinthian:

Pointing to an affluent Corinthian, the above-mentioned Xeniades, he said, 'Sell me to him; he needs a master.' Thus Xeniades purchased him, took him home to Corinth, put him in charge of his own sons, and entrusted him with his entire household. And Diogenes performed all his duties in such a manner that Xeniades went about saying, 'A kindly deity has entered my house. 48

Diog. Laert. 6.74

Diogenes shamelessly claims that Xeniades needs a master, the slave choosing the master overturns the traditional standard of the master choosing the slave. But rather than cause a scandal, Diogenes is accepted into the charge of Xeniades whose power is shown to be dependent on slaves to run his household. Diogenes challenges the power structure by becoming almost godlike in his position. The slave is seen as the master of the master. ${ }^{49}$ Similarly, Diogenes also undermines the authority of Alexander, who when asked what would he wish from the great ruler, Diogenes said to get out of his light. ${ }^{50}$ The reversal of agency makes visible the contingent nature of power and the opposition between the freedom that comes from having nothing and the apparent power that comes from having almost everything. ${ }^{51}$ Recognizing the contingent nature of freedom and servitude or power and powerlessness stands as immanent critique because it makes clear that the virtues of power for instance for Alexander, are not independent of the virtues of the powerlessness as demonstrated by Diogenes. Within the structure of oikonomics and politics, slavery and kingship are opposed and mutually interconnected.

praxis in antiquity, and sets in motion an almost 'Hegelian' dialectic of action (for instance with the opposition of nature and custom) without the trappings of idealism and the transformation to pure spirit.

48 Mensch trans., (2018). Translation amended.

49 In a similar vein the Life of Aesop (Vita Aesopi) presents the master slave dialectical relationship with a reversal of power.

$50 \quad$ Diog. Laert. 6.38; Cicero Tusc. 5.32.92; Plut. Alex. 14; Plut. De exil.15.

$5^{1}$ See the account of Alexander and Diogenes from Dio. Chrys. Or. 6. 
Diogenes' view about polis life and the concomitant normative behavior within it are not merely opposed to the Cynic's endorsement of the value of our nature kata phusin. Diogenes surprisingly admits that custom and law are required for the polis to offer benefits to the citizens. This is a controversial point that goes against the more standard readings of Cynic naturalism, but it is crucial to understand how the relationship of nature to custom is dialectical. The view that Diogenes endorses the need for custom and the polis is supported from the following:

As for law, he held that without it one cannot be a citizen. For he said that without a city there is no means of obtaining the benefits of being civilized. The city is civilized; its advantages cannot be enjoyed without law; and therefore the law is a civilized thing. He would make fun of good birth, reputation, and all such things, calling them the evil adornments, and held that the correct constitution was only that which was in the world.

Diog. Laert. 6.72

This passage is sometimes seen as merely ironic, but it is not necessarily so. ${ }^{52}$ First, without a city, there are no benefits from being cultivated because it is only in virtue of a city that it is possible to be a citizen. And it is in virtue of being a citizen that it is possible to be civilized or cultivated. But it is also necessary for a citizen to be cultivated and civilized by custom and law, even if they are normative practices. This is because the values that the city can offer, education, safety, food production, and all the rest, are a consequence of nomos and not merely phusis. Nomos establishes as a law or custom actions that might be kata phusin, but in establishing a habit, practice, or custom, they are bound up kata nomon. An ironic reading of this passage stresses that the value ascribed to being a citizen is dodgy because it arises from the laws and customs of the city - where false virtue resides willy-nilly. Nevertheless, the dependence on the city is underserved by the ironic reading because it makes possible the view that the Cynic can exit from the social and political structure because there is no real value in the laws and customs of the city. It makes possible the reading that the Cynic is an anti-state naturalist. But the Cynic, and in particular Diogenes, is never entirely outside the purview of the polis, even if they reside on the margins, or in marginal ways. In fact, I have already argued

$5^{2}$ J. Moles, 'The Thirteenth Oration of Dio Chrysostom: Complexity and Simplicity, Rhetoric and Moralism, Literature and Life', The Journal of Hellenic Studies 125 (2005), pp. 112-138; M. Schofield, The Stoic Idea of the City (Cambridge Press: Cambridge, 1991). 
that the marginalization of the Cynic, the Cynic in exile, is instrumental to the kind of provocation that is proper to Cynicism.

Being 'civilized' then carries this double meaning, both the charm and refinement that would attract the ridicule of Diogenes, and the aspects of normative behavior that allow for things like social cohesion and production. One might be tempted to revert back to the view that the world (kosmos) is the only correct 'city', reducing the world to a polis or worse elevating a city to the world. Both are unnecessary. First, the advantages (ophelos) of the city that are associated with being cultivated (asteios) need not be determined as wholly positive or ironic and wholly negative. There are advantages to being part of the polis, even if the behavior of citizens is often overly guided by the smoke of false coin. One might consider that the norms can be reconsidered, and social and political arrangements are works in progress.

The final sentence in our passage lambasts good birth and reputation as 'evil adornments' (prokosmèmata), but it does not demand that these are necessary consequences from any and every arrangement of a polis. These evil aspects are contingent evils that arise from bad arrangement of our norms. And the correct 'constitution,' (politeia) as he would have it, only in or of the world (kosmos), does not need to abandon the polis, since as I have argued, the world does not restrict the city or many cities from being components of it. Therefore, the correct arrangement of our social and political aspects only requires considering the arrangement with respect to phusis in a way that admits of the polis and the potential value within. Thus, the passage affirms rather than rejects the duality of politeia which is inclusive of the state of our nature with the state.

It is my view that Diogenes' Cynicism confronts his audience with the possibility of social reform through the performance of a philosophical praxis that makes evident the contingent aspects of social normativity and conformity. First, in making clear that some of the normative standards are irrational, unthoughtful, hypocritical, or generally problematic, Diogenes alerts his audience to the possibility of reconsidering the social norms. Second, in making clear the contradictory aspects inherent in polis life, such as nature and custom, freedom and dependence, courage and luck, and all the rest, Diogenes' praxis performs an immanent social critique without endorsing wholesale one fixed way of life. In its place, Diogenes shows the interconnected polarity between the extremes, the oppositions and contradictions that populate polis life. Making visible these oppositions inherent in the society makes it possible, 
and in some way even demands that we recognize if not fully reassess the norms for the sake of overcoming the problematic aspects if and when they are shown to be false coin. This requires that the public are sufficiently alerted to the fact that the powerful are also dependent, and that the social order based on a constitution can vary from Athens to Corinth to Sparta etc., without having the need for any single universal model as the ideal in itself.

The oppositional aspects that are illuminated by the Cynic's lantern are already always part and parcel to living in a polis, and this is why Diogenes can be seen to perform immanent critique. Because the standards of custom and law utilized for the harmonization of the polis are not universal or predetermined, but normative, and they are constrained by and contrasted to their opposing non-civilized natural desires and drives, the Cynic conveys both the need for and possibility of a transvaluation of value. But it is up to us to take up the task, and to transform Cynic praxis as provocation into social and political action and reformation. The Cynic acts as the spark that lights the way out of unreflective conformity to hegemonic but nevertheless normative forces, and offers us the possibility, much like Diogenes himself, to reconfigure and transform our own lives. As Diogenes transforms his own life from exiled Sinopean to Cynic Philosopher in virtue of reassessing what it means to deface the coinage, so too does the Cynic philosopher ask us to reassess our custom and coin, in order to potentially transform our own commitments, and collectively our own polity to improve so as to better reflect our best nature. Our politeia is a work in progress, and so, just as for Herakles who was the divine reflection of the Cynic figure - time to start shoveling. ${ }^{53}$

53 Dio Chrys. Or. 8.35-36 (Cohoon (trans.), 1939): 'While Diogenes thus spoke, many stood about and listened to his words with great pleasure. Then possibly with this thought of Heracles in his mind, he ceased speaking and, squatting on the ground, performed an indecent act ....' 